\title{
THYMUS VULGARIS EXTRACT FORMULATED AS CYCLODEXTRIN COMPLEXES: SYNTHESIS, CHARACTERIZATION, ANTIOXIDANT ACTIVITY AND IN VITRO CYTOTOXICITY ASSESSMENT
}

\author{
IOANA TUȚĂ-SAS ${ }^{1 \#}$, MARIA PROKS ${ }^{1,2 \#}$, VIRGIL PĂUNESCU ${ }^{1}$, IULIA PÎNZARU ${ }^{2 *}$, IOAN \\ SAS $^{1}$, DORINA CORICOVAC ${ }^{2}$, ALINA MOACA $^{2}$, CRISTINA DEHELEAN $^{2}$ \\ ${ }^{I}$ Faculty of Medicine, "Victor Babeş” University of Medicine and Pharmacy Timişoara, 2 Eftimie Murgu Square, 300041 \\ Timişoara, Romania \\ ${ }^{2}$ Faculty of Pharmacy, "Victor Babeş” University of Medicine and Pharmacy Timișoara, 2 Eftimie Murgu Square, 300041 \\ Timişoara, Romania
}

*corresponding author: iuliapinzaru@umft.ro

${ }^{\#}$ Authors with equal contribution

Manuscript received: January 2019

\begin{abstract}
Thymus species are important sources of bioactive compounds but considering their low stability and solubility in aqueous solutions, the pharmaceutical utilization is limited. A method to overcome these drawbacks was proposed in the current study, by encapsulating thyme total hydro-alcoholic extract (TE) in $\beta$ - and $\gamma$ - CD (cyclodextrins). It was assessed the antioxidant activity (AOA) in time (DPPH assay) and the in vitro cytotoxicity on MCF-7 and MDA-MB-231 breast cancer cells, using the Alamar blue test (cells viability), scratch assay technique (cells migration and proliferation) and Annexin VFITC assay (cells apoptosis). The TE and its CD complexes showed a significant AOA over a longer time interval indicating a controlled release of the active compounds. In vitro tests indicated a significant cytotoxic activity of both CD complexes as compared to TE, even at a low concentration $(10 \mu \mathrm{g} / \mathrm{mL})$, the most pronounced activity being recorded for TE $\gamma$-CD inclusion complex on MDA-MB-231 cells (32\% viable cells at $100 \mu \mathrm{g} / \mathrm{mL})$.
\end{abstract}

\section{Rezumat}

Speciile de Thymus sunt surse importante de compuși bioactivi, dar având în vedere stabilitatea și solubilitatea scăzute în soluții apoase, utilizarea farmaceutică a acestora este limitată. În studiul de față, pentru corectarea acestor dezavantaje s-a recurs la încapsularea extractului hidroalcoolic total de cimbru (TE) în $\beta$ - şi $\gamma$-CD (ciclodextrine). Ulterior, a fost evaluată activitatea antioxidantă (AOA) în dinamica temporală (prin metoda DPPH) şi citotoxicitatea in vitro pe celulele de cancer mamar MCF-7 și MDA-MB-231, prin testul Alamar blue (viabilitatea celulară), prin testul scratch (migrarea și proliferarea celulară) și testul Annexin V-FITC (apoptoza celulară). TE și complecşii acestuia cu CD au prezentat o AOA semnificativă pe un interval de timp mai lung, indicând o eliberare controlată a compuşilor activi. Testele in vitro au indicat o activitate citotoxică semnificativă a ambilor complecși cu CD comparativ cu TE, chiar și la o concentrație scăzută $(10 \mu \mathrm{g} / \mathrm{mL})$, activitatea cea mai pronunțată fiind înregistrată pentru complexul de incluziune TE $\gamma$-CD pe celulele MDA-MB-231 (32\% celule viabile la $100 \mu \mathrm{g} / \mathrm{mL})$.

Keywords: thyme, cyclodextrin, breast cancer, viability, apoptosis

\section{Introduction}

In the last decades, the application of natural and traditional herbal treatments increased remarkably and presents multiple advantages, including improved efficacy in different medical fields. The augmentation of drug resistance determined the researchers to concentrate on finding new sources of effective medicines what led to the development of phytotherapy. Currently, the pharmaceutical industry relies on almost $50 \%$ formulations based on plants and herbs, and traditional and complementary and alternative medicine influenced the current approach of many pathologies by highlighting the major role of phytochemicals and nutraceuticals $[2,16]$. Extracts obtained from various aromatic and medicinal plants can serve as new pharmaceutical remedies [12]. Aromatic plants of high therapeutic importance include also Thymus vulgaris, one of the $\sim 300$ species of the Thymus genus. All Thymus species are recognized for their antiseptic, antimicrobial and more recently, antitumoral properties, being used as traditional therapy [12].

A compound possesses biological activity if fulfils the following conditions: ability to cross the cell membrane, to keep its integrity during the absorption and distribution processes, and to reach the target site of action regardless of molecular structure. With regard to phytochemicals, they have a low stability and solubility, what leads to a reduced bioavailability, restricting their use in the pharmaceutical field for 
FARMACIA, 2019, Vol. 67, 3

prophylactic and curative purposes. A promising alternative to improve their properties is to include them in molecules of natural origin (e.g. cyclodextrins) that are considered safe from a toxicological point of view $[13,15]$. Cyclodextrins are part of the class of the most widely used molecules in host-guest chemistry, with application in the food, cosmetic and pharmaceutical fields. Native cyclodextrins, $\alpha$-, $\beta$ - and $\gamma-$, are obtained by the treatment of starch with amylase isolated from the Bacillus macerans strain [14]. The use of cyclodextrins in the pharmaceutical domain is approved by FDA, and are considered exceptional drug carriers, due to their property to encapsulate lipophilic molecules through non-covalent interactions [17, 21].

Breast malignancies are the leading cause of death among women over 40 years old, with an estimated annual diagnosis of over 1 million cases $[5,11]$. Moreover, the increased morbidity among patients may be related to the current treatment approach surgery, both radio- and chemo- therapies $[5,11]$. Therefore, finding new therapeutic approaches to reduce morbidity in cancer patients is a challenge for all scientists involved (chemists, biologists, pharmacists, physicians), and is directly related to natural resources, especially medicinal plants.

The main purposes of this study were: to obtain, to characterize, and to assess the in vitro activity of hydro-alcoholic total extract from Thymus vulgaris (TE), and its inclusion complexes in $\beta$ - and $\gamma$ cyclodextrin (TE/bCD and TE/gCD), on two breast cancer cell lines with different receptor expression MCF-7 (oestrogen receptor) and MDA-MB-231 (nonoestrogen receptor with epidermal growth factor EGF and transforming growth factor alpha - TGF alpha expressed).

\section{Materials and Methods}

\section{Reagents}

$\beta$-cyclodextrin and $\gamma$-cyclodextrin were purchased from Cyclolab Hungary; 1,1-diphenyl-2-picrylhydrazyl (DPPH) from Sigma Aldrich, Germany; ascorbic acid from Lach-Ner, Czech Republic; Folin-Ciocalteu reagent (Sigma-Aldrich; Merck KGaA), all standard compounds, reagents and solvents were purchased from Sigma-Aldrich, Germany. All substances were used as received.

Extract and inclusion complexes preparation Thymus vulgaris (thyme) was received as a gift from Favisan Laboratories Lugoj and a voucher specimen (no. CD_004_1) is preserved at the Herbarium of the Faculty of Pharmacy, "Victor Babes" University of Medicine and Pharmacy Timisoara, Romania.

Thyme dried aerial parts $(50 \mathrm{~g})$ were extracted by maceration with $70 \%$ ethanol $(100 \mathrm{~mL})$ for 24 hours. The resulted solution was filtered, subjected to evaporation by means of a rotary evaporator under vacuum, and the resulting mass was lyophilized and stored at $-20^{\circ} \mathrm{C}$, until further determinations.

The TE cyclodextrin inclusion complexes were prepared according to a kneading method previously described in the literature [8] with some minor changes: a simple powder mixing of the total lyophilized extract and cyclodextrin in 1:2 molar ratio (the molar ratio was chosen based on the hypothesis that the total extract was a bioactive compound - rutin, $\mathrm{Mm}_{\text {Rutin }}=$ $610.52 \mathrm{~g} / \mathrm{mol}, \mathrm{Mm}_{\mathrm{bCD}}=1134.98 \mathrm{~g} / \mathrm{mol}$ and $\mathrm{Mm}_{\mathrm{gCD}}=$ $1297.128 \mathrm{~g} / \mathrm{mol}$ ) using a mortar and a pestle, followed by kneading with an ethanolic solution $(50 \% \mathrm{w} / \mathrm{w}$ water: ethanol) until the solvent evaporation and a paste-type mass formation. The final supramolecular system was obtained after drying at room temperature for at least $24 \mathrm{~h}$, followed by drying in the oven at $105^{\circ} \mathrm{C}$, for several hours until reaching a constant weight. The physical mixture of the compounds was used for comparative formation studies of inclusion compounds.

Physico-chemical characterization

Total polyphenols, flavonoids, flavonols, and tannins were determined by well-known and frequently used spectrophotometric methods: (1) total phenols (TP) by Folin-Ciocalteu method - extract samples were treated with Folin-Ciocalteu aqueous reagent (1:10 dilution), incubated for 300 seconds at room temperature, followed by addition of sodium carbonate, heated at $50^{\circ} \mathrm{C}$ and absorbance measurements at $750 \mathrm{~nm}$ using an UV-VIS spectrophotometer (Specord 205; Analytik Jena), the results were expressed in mg GAE/g dry material; (2) flavonoids/flavonols (TF/TFv) by Al colorimetric test - extract samples were treated with $2 \% \mathrm{AlCl}_{3}$ solution and the absorbance measurements were performed at $417 \mathrm{~nm}$ and $445 \mathrm{~nm}$, respectively; the results were expressed as rutin equivalents (RE); (3) total condensed tannin (TT) by vanillin test, extract samples were treated with vanillin solution and the absorbance measurements were registered at $500 \mathrm{~nm}$, the results were expressed as milligrams of (+)-catechin equivalents (mg CE/g extract). All experiments were performed in triplicate.

LC-MS analysis. Quantitative analysis of polyphenolic compounds was conducted on Shimadzu chromatograph: detectors - SPD-10A UV and LC-MS 2010; column EC 150/2 NUCLEODUR C18 Gravity SB $150 \times 2$ $\mathrm{mm}$ x $5 \mu \mathrm{m}$; chromatographic conditions, mobile phase $\mathrm{A}$ - water acidified with $\mathrm{HCOOH}$, mobile phase $\mathrm{B}-\mathrm{C}_{2} \mathrm{H}_{3} \mathrm{~N}$ acidified with $\mathrm{HCOOH}$, gradient program: 0' - 20' 5\% B, 20' - 50' 5\% -40\% B, 5' - 55', $40 \%$ - $95 \%$ B, 55 ' - 60 ' $95 \%$ B; f.r. of $0.2 \mathrm{~mL} / \mathrm{min}$; temperature $20^{\circ} \mathrm{C}$; wavelengths $280 \mathrm{~nm}$ and $320 \mathrm{~nm}$. Experiments were conducted in duplicate.

Scanning Electron Microscopy (SEM). To evaluate supramolecular system morphology, the inclusion complexes were examined by scanning electron microscopy (Hitachi S4700, Hitachi Scientific Ltd., Tokyo, Japan) and a sputter coating apparatus was 
utilized for the induction of electric conductivity on the surface of the samples.

Differential Scanning Calorimetry (DSC). To verify the complexes behaviour and to confirm the formation of inclusion complexes it was used a thermal analysis system device Mettler Toledo DSC 821e with STARe V6.0 program (Mettler Inc., Schwerzenbach, Switzerland); $\sim 2$ - $4 \mathrm{mg}$ of tested compounds were examined in the temperature range of $25^{\circ} \mathrm{C}$ and $350^{\circ} \mathrm{C}$ with the heating rate $10^{\circ} \mathrm{C} / \mathrm{min}$ and Argon used as carrier gas, at a flow rate of $10 \mathrm{~L} / \mathrm{h}$.

FTIR analysis. This test was performed using the FT-IR Jasco 430 spectrophotometer in the frequency range of $4000 \mathrm{~cm}^{-1}$ and $400 \mathrm{~cm}^{-1}$. Solid samples subjected to analysis were prepared in potassium bromide pills and IR spectra of supramolecular systems were processed and compared with the spectra of pure $\beta$ - and $\gamma$ - cyclodextrins, thyme total extract and their physical mixtures.

Antioxidant activity. Evaluation of the antioxidant activity of these complex systems was performed using separate solutions of TE $(1 \mathrm{mg} / \mathrm{mL})$ and TE complexes $(4 \mathrm{mg} / \mathrm{mL})$. The antioxidant activity analysis was performed using a T70 UV/VIS Spectrophotometer (PG Instruments Ltd.), and the data obtained were processed using the UV-Win software version V5.2.0.1104. A mixture of $2 \mathrm{~mL} 96 \%$ ethanol (or 2 $\mathrm{mL}$ of distilled water), $0.5 \mathrm{~mL}$ of sample solution, alcoholic or aqueous, and $0.5 \mathrm{~mL}$ of $1 \mathrm{mM}$ DPPH solution was prepared, and the absorbance was recorded at $517 \mathrm{~nm}$ for $900 \mathrm{~s}$. The solution discolours over time as DPPH reacts with the free radicals or their precursors in the system, and the progress of the reaction is monitored spectrophotometrically. All readings were reported to an alcoholic or aqueous reference solution.

Cell culture

HaCaT - immortalized human keratinocytes (ATCC American Type Culture Collection) and MDA-MB231 (ATCC ${ }^{\circledR}$ HTB-26 ${ }^{\mathrm{TM}}$ ) human breast cancer cells were cultured in DMEM (Dulbecco's Modified Eagle's Medium, Sigma Aldrich) supplemented with 10\% FCS (foetal bovine serum, Sigma-Aldrich, Germany) and $1 \%$ penicillin-streptomycin (Pen/Strep 10,000 U/ $\mathrm{mL}$; Gibco). MCF-7 (ATCC ${ }^{\circledR}$ HTB-22 ${ }^{\mathrm{TM}}$ ) human breast cancer cells were cultured in EMEM (Eagle's Minimum Essential Medium, ATCC) supplemented with $10 \%$ FCS (foetal bovine serum, Sigma-Aldrich, Germany) and 1\% penicillin-streptomycin (Pen/Strep 10,000 U/mL; Gibco). During the experiment, all cell lines were kept in standard conditions: incubation at $37^{\circ} \mathrm{C}$ in $5 \% \mathrm{CO}_{2}$ atmosphere. The following sample concentrations were tested: 10,50 and $100 \mu \mathrm{g} / \mathrm{mL}$. Alamar blue assay. Resazurin sodium salt (SigmaAldrich, Germany) was used as bioreagent to determine cell viability, and was therefore dissolved in PBS (Phosphate Buffered Saline, Fisher BioReagents, USA) to obtain a suitable Alamar Blue solution. Cells were allowed to adhere to 96-well culture plates $\left(1 \times 10^{4}\right.$ cells/well) until the appropriate confluence was reached (24 - $48 \mathrm{~h}$ ). Then, the cells were stimulated with $200 \mu \mathrm{L}$ of new medium containing the tested substances $(10$, 50 , and $100 \mu \mathrm{g} / \mathrm{mL}$ ). Substances were allowed to interact for $24 \mathrm{~h}$ with the cells, followed by addition of Alamar Blue solution to each well $(20 \mu \mathrm{L} /$ well $)$. After $3 \mathrm{~h}$ of incubation at $37^{\circ} \mathrm{C}$, absorbance was read at two wavelengths (570 and $600 \mathrm{~nm})$. The spectrometer (TECAN, infinite M 200 PRO, Austria) was used to read the absorbance values. The results were obtained in quadruplicate. Unstimulated cells were used as a reference/control.

Scratch assay. The cellular ability to migrate and proliferate was assessed by means of a wound healing type technique - scratch assay. Briefly, $2 \times 10^{5}$ cells/ well were seeded in 12-well plates, and when a $90 \%$ confluence was obtained, a scratch was drawn in the middle of the well with a $10 \mu \mathrm{L}$ sterile tip. To observe the effect of the TE, TE/ $\beta C D$, and TE $/ \gamma \mathrm{CD}$ $(10 \mu \mathrm{g} / \mathrm{mL})$ in terms of proliferation and migration, the difference between the initial and after $24 \mathrm{~h}$ wound width, was studied and pictures at $10 \times$ magnification have been made with an Olympus IX73 inverted microscope equipped with DP74 camera (Olympus, Tokyo, Japan).

Annexin V/PI apoptosis assay. MCF-7 and MDAMB-231 human breast cancer cells were seeded into 6 -well plates $\left(3 \times 10^{5}\right.$ cells/well) in order to study cell apoptosis. For this purpose, flow cytometry analysis were performed using an Annexin V-FITC kit (eBioscience, Viena, Austria). Selected concentrations $(10,50$ and $100 \mu \mathrm{g} / \mathrm{mL})$ of tested compounds were added. After $24 \mathrm{~h}$ of treatment, cells were washed with $500 \mu \mathrm{L}$ PBS and centrifugated for $5 \mathrm{~min}$ at $1500 \mathrm{rpm}$. The cells were resuspended in $200 \mu \mathrm{L}$, and a mixture of $195 \mu \mathrm{L}$ Annexin $\mathrm{V}$ binding buffer and $5 \mu \mathrm{L}$ of FITC-conjugated Annexin V was added to cell suspension. The samples were incubated for 15 min at room temperature in the dark. Finally, after two more consecutive wash steps with $200 \mu \mathrm{L}$ binding buffer, $10 \mu \mathrm{L}$ of propidium iodide solution $(20 \mu \mathrm{g} / \mathrm{mL})$ were added. The samples were analysed by flow cytometry (FACS Calibur; Becton Dickson, Franklin Lakes, NJ, USA). Cells that were not exposed to the tested substances were used as control.

\section{Statistical analyses}

The analysis program and software utilized in the current study were GraphPad Prism 7 and Flowing Software Version 2.5.1. Results were interpreted using one-way ANOVA, followed by Tukey's posttests when appropriate, to establish the statistical difference between experimental and blank lots; *, **, $* * *$ and $* * * *$ indicate $\mathrm{p}<0.05, \mathrm{p}<0.01, \mathrm{p}<0.001$ and $\mathrm{p}<0.0001$, respectively. The obtained results are shown as mean value of three experiments \pm standard deviation. 


\section{Results and Discussion}

The chemical composition of plant extracts varies significantly depending on several parameters, such as: climatic influences, growing and harvesting processes, genetic variability, and the type of processing and extraction methods chosen - solvent, extraction period, temperature, etc. $[6,9,20]$.
The extraction yield percentages of the total extracts obtained from aerial parts of thyme by using $70 \%$ ethanol (maceration) are presented in Table I, together with the total content of different classes of biologically active compounds. The highest quantity of phenols (TPC), flavonoids (TFC), flavonols (TFvC) and tannins (TT) were detected in the TE.

Table I

Total phenolic, flavonoid, flavonols and tannins content found in the extracts of Thymus vulgaris $(\mathrm{n}=3$, mean $\pm \mathrm{SD})$

\begin{tabular}{cccccc}
\hline Extract & $\begin{array}{c}\text { Extraction yields } \\
(\%)\end{array}$ & $\begin{array}{c}\text { TPC } \\
(\mathrm{mg} \mathrm{GAE} / \mathrm{g} \mathrm{dm})\end{array}$ & $\begin{array}{c}\text { TFC } \\
(\mathrm{mg} \mathrm{RE} / \mathrm{g} \mathrm{dm})\end{array}$ & $\begin{array}{c}\text { TFvC } \\
(\mathrm{mg} \mathrm{RE} / \mathrm{g} \mathrm{dm})\end{array}$ & $\begin{array}{c}\text { TT } \\
(\mathrm{mg} \mathrm{CE} / \mathrm{g} \mathrm{d} . \mathrm{m} .)\end{array}$ \\
\hline $\mathrm{TE}$ & 22.7 & $37.2 \pm 1.6$ & $43.8 \pm 0.6$ & $3.6 \pm 1.1$ & $16.8 \pm 0.6$
\end{tabular}

The individual quantitative analysis of bioactive phytocompounds like polyphenols, revealed the amounts of each type of molecule found in the total hydro alcoholic extract of thyme, rosmarinic acid, rutin and kaempherol being the major compounds.
As can be observed in Table II, caffeic acid and quercetin are found in sufficient quantities. The identity of the compounds was certified by HPLC-MS by comparison with analytical standard of each compound.

Major phenolic compounds (\% of total) identified in Thymus vulgaris total hydro alcoholic extract by HPLC-MS

\begin{tabular}{|c|c|c|c|}
\hline Sample & Compound name & Retention time & Concentration $(\mu \mathrm{g} / \mathrm{g})$ \\
\hline \multirow[t]{11}{*}{ TE } & Gallic acid & 4.876 & 1.492 \\
\hline & Protocatechuic acid & 11.181 & 0.626 \\
\hline & Caffeic acid & 21.180 & 52.081 \\
\hline & Epicatechin & 22.125 & 26.618 \\
\hline & p-Coumaric acid & 24.573 & 0.246 \\
\hline & Ferulic acid & 23.455 & 5.417 \\
\hline & Rutin & 25.122 & 1285.389 \\
\hline & Rosmarinic acid & 27.418 & 1490.881 \\
\hline & Resveratrol & 29.745 & 8.637 \\
\hline & Quercetin & 31.839 & 75.329 \\
\hline & Kaempferol & 35.451 & 1083.883 \\
\hline
\end{tabular}

Natural bioactive compounds present increased sensitivity to degradation and inactivation, facts that led to a rapid development of protection techniques with the mandatory requirement to secure the bioactive compounds from chemical degradation (oxidation, hydrolysis) without altering their properties [10, 21]. Inclusion in cyclodextrins leads to encapsulated compounds protected from the action of external factors that can be released gradually into the biological aqueous environment due to the association-dissociation equilibrium that occurs [8]. In the case of TE, after the complexing process, high recovery rates were obtained: from $72.3 \% \mathrm{TE} / \beta \mathrm{CD}$ complex and to $84.6 \%$ $\mathrm{TE} / \gamma \mathrm{CD}$ complex. The $\beta \mathrm{CD}$ complex was obtained with a slightly lower yield, probably due to a higher solubility of this complex in the ethanol-water solution used for complexation. FT-IR spectroscopic analysis confirms the interaction between the extract and the cyclodextrins and implicitly the formation of their complexes. The FT-IR spectra of the complexes were compared to those of pure substances (extract and cyclodextrins). The absorption bands characteristic for extract and cyclodextrins were also found in the spectra of the complexes confirming that the extract was encapsulated. In Figures 1 and 2 are presented the $\beta C D$ and TE/ $\beta C D$ complexes, where the characteristic bands of the phenolic hydroxyl groups are less intense for the complex, at $3421 \mathrm{~cm}^{-1}$ and $1600 \mathrm{~cm}^{-1}$, and the characteristic $\beta C D$ band, $v_{\mathrm{COC}}$ at $1027 \mathrm{~cm}^{-1}$, is also found in complex as equally intense at $1026 \mathrm{~cm}^{-1}$. The same characteristic signals can be noticed within the complex with $\gamma \mathrm{CD}$. The DSC technique can highlight the thermal degradation and thermal-oxidative degradation processes of materials of inorganic and organic nature and the DSC curve is specific to each material; therefore, this approach can be considered as a thermal spectroscopy method by which a material can be identified [19]. The DSC profiles of extract, pure cyclodextrins and their inclusion complexes were analysed. $\beta C D$ and $\gamma \mathrm{CD}$ present a large endothermic peak before $95^{\circ} \mathrm{C}$ and $80^{\circ} \mathrm{C}$, denoting the gradual loss of $\mathrm{H}_{2} \mathrm{O}$ while TE/CD complexes displays a very large endothermic peak with the onset around 85 $90^{\circ} \mathrm{C}(\mathrm{TE} / \beta \mathrm{CD})$ and $65-70^{\circ} \mathrm{C}(\mathrm{TE} / \gamma \mathrm{CD})$. The formation of supramolecular systems is showed by the modification of the water dissociation energy (WDE) from $1290 \mathrm{~mJ}(\beta \mathrm{CD})$ to $892.26 \mathrm{~mJ}(\mathrm{TE} / \beta \mathrm{CD})$ and from $435.92 \mathrm{~mJ}(\gamma \mathrm{CD})$ to $182.85 \mathrm{~mJ}(\mathrm{TE} / \gamma \mathrm{CD})$, respectively (see Figures 1 and 2). $\beta C D, T E / \beta C D, \gamma C D$ and $\mathrm{TE} / \gamma \mathrm{CD}$ were investigated by SEM to establish 
the morphology of the compounds. The compounds were analysed at $100 \mu \mathrm{m}$ scale with 800 magnification and the micrographs present the crystalline nature of the CDs with variable dimensions and irregularities in orientation and structure with the aggregation capacity (Figures 1 and 2). The physical mixture of extract and cyclodextrin (data not included) presents a different shape and structure. Both inclusion complexes exhibited an amorphous form and the presence of small particles with various shaped and cluster formation with different sizes.
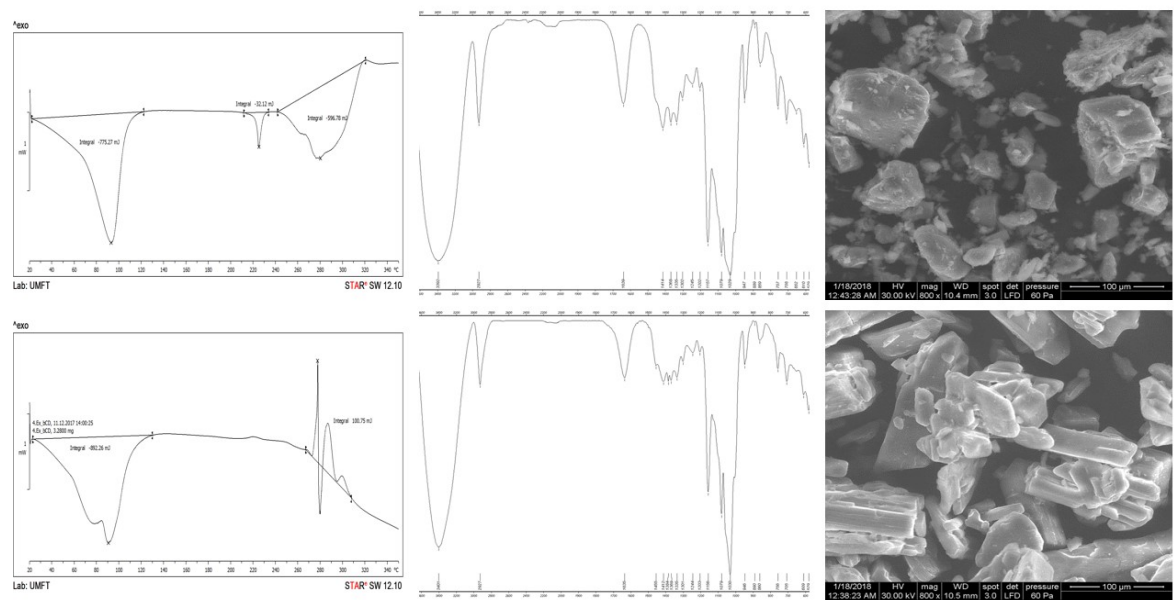

Figure 1.

DSC analysis of $\beta C D$ (up) and TE/ $\beta C D$ (down) on the temperature range $25-350^{\circ} \mathrm{C}$; FTIR spectra of $\beta C D$ (up) and TE/ $\beta C D$ (down) in the range of $4000-400 \mathrm{~cm}^{-1}$; TEM images of the compounds $\beta C D$ (up) and TE/ $\beta C D$

(down) - scale bars are $100 \mu \mathrm{m}$
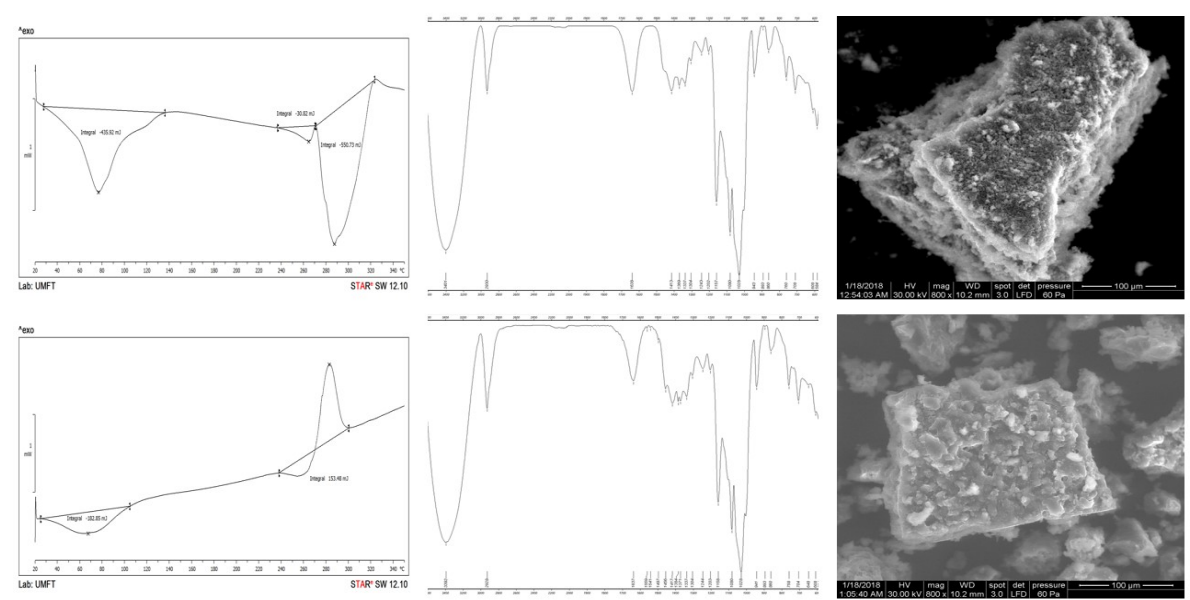

Figure 2.

DSC analysis of $\gamma \mathrm{CD}$ (up) and TE/ $\gamma \mathrm{CD}$ (down) on the temperature range $25-350^{\circ} \mathrm{C}$; FTIR spectra of $\gamma \mathrm{CD}$ (up) and $\mathrm{TE} / \gamma \mathrm{CD}$ (down) in the range of $4000-400 \mathrm{~cm}^{-1}$; TEM images of the compounds $\gamma \mathrm{CD}$ (up) and TE/ $\gamma \mathrm{CD}$

(down) - scale bars are $100 \mu \mathrm{m}$

The antioxidant activity of plant extracts and/or bioactive compounds can be assessed by spectrophotometric methods using the DPPH radical capture method. One aspect which must be considered in these studies is the competitivity of the reactant at the biocompatible/ cyclodextrin-binding/dissociation balance. An important indicator that cumulates these aspects is the reaction rate of DPPH in the presence of samples to be analysed, suggesting the reactivity of the compounds with antioxidant activity, i.e. the possibility of their controlled release from the complexes with cyclo- dextrins. Although the final antioxidant activity is significant, an insignificant reaction rate of $\mathrm{DPPH}$ over the final time interval indicates that there is no antioxidant effect (high reactivity and/or no controlled release for the antioxidant compound). The antioxidant activity was calculated as a difference from 100 percent of the absorbance at time $t$ relative to initial absorbance (the ratio between " $\mathrm{t}$ " time absorbance and initial absorbance at $517 \mathrm{~nm}$ ), expressed as a percentage, as previously published in our studies [18]. To evaluate the behaviour of bioactive compounds 
studied in the presence of reactive species in the human body (e.g. reactive oxygen species, ROS, free radicals, etc.), DPPH reaction rates were determined on the pseudo linear portions of the concentration-time variation curves. The antioxidant activity (Figure 3 ) for
$\mathrm{TE}$ and the corresponding $\beta \mathrm{CD}$ and $\gamma \mathrm{CD}$ complexes (at comparable extract concentrations) is $\sim 71 \%, \sim 81 \%$ and $\sim 56 \%$ respectively. However, reaction rates of DPPH at representative time intervals $(10-60 \mathrm{~s}, 60$ $180 \mathrm{~s}$ and $180-900 \mathrm{~s}$ ) are relatively close.

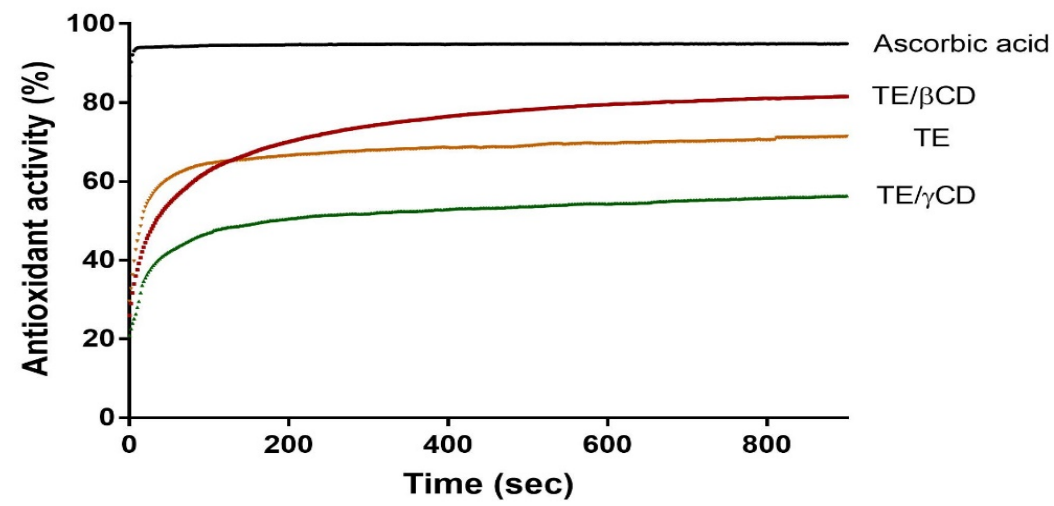

Figure 3.

Representation of antioxidant activity (AOA \%) over time for thyme total hydro-alcoholic extract (TE) and its inclusions complexes in $\beta$ - and $\gamma$ - cyclodextrins (TE/ $\beta C D$ and $\mathrm{TE} / \gamma \mathrm{CD}$ )

To evaluate the activity exerted by the thyme total hydro-alcoholic extract and its cyclodextrin inclusion complexes on normal human $(\mathrm{HaCaT})$, and breast cancer (MCF-7 and MDA-MB-231) cells viability, it was selected the Alamar blue test. Viability and proliferation assay with Alamar blue is an indicator based on detection of metabolic activity. Reduction related to growth causes the redox indicator to change from oxidized (blue) form to reduced (red).

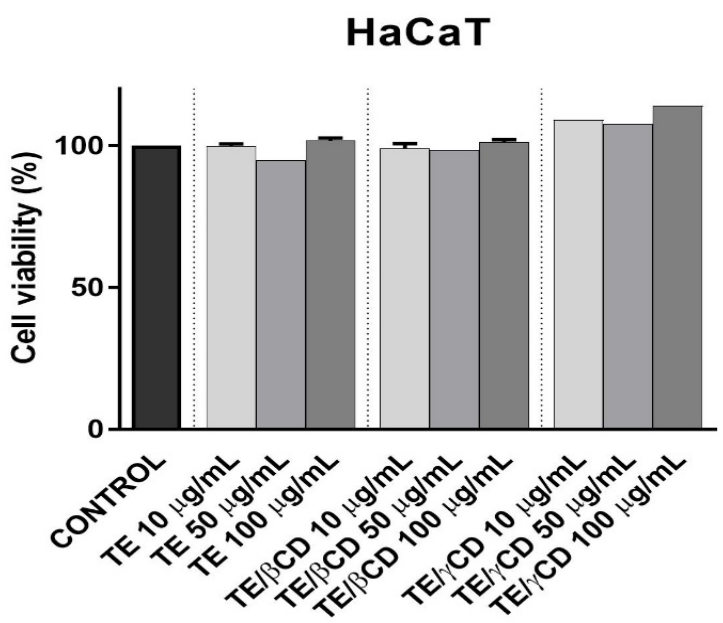

Figure 4.

Viability percentage of $\mathrm{HaCaT}$ (human keartinocytes) at $24 \mathrm{~h}$ post-stimulation with thyme total hydroalcoholic extract and its inclusions complexes with $\beta$ - and $\gamma$ - cyclodextrins $(10,50$ and $100 \mu \mathrm{g} / \mathrm{mL})$
Stimulation of keratinocytes with TE, TE/ $\beta C D$ and $\mathrm{TE} / \gamma \mathrm{CD}$ showed a slight increase in cells viability as can be observed in Figure 4, especially for TE/ $\gamma \mathrm{CD}$ $(\sim 109 \%$ viable cells at $10 \mu \mathrm{g} / \mathrm{mL}, \sim 108 \%$ viable cells at $50 \mu \mathrm{g} / \mathrm{mL}$ and $\sim 114 \%$ viable cells at 100 at $\mu \mathrm{g} / \mathrm{mL}$, respectively) as compared to control cells (unstimulated cells). Pure tested cyclodextrins have no noticeable influence on cells viability.

Stimulation of human breast cancer cells (MCF-7 and MDA-MB-231) was performed in the same conditions as applied for normal cells, in order to assess the cytotoxic activity of TE, TE/ $\beta C D$ and $\mathrm{TE} / \gamma \mathrm{CD}(10,50$ and $100 \mu \mathrm{g} / \mathrm{mL})$ for $24 \mathrm{~h}$. Data revealed that inclusion complexes of thyme total hydro-alcoholic extract exerted a significant decrease in cell viability percentage, cell-type dependent. In the case of MCF-7, TE produced a minor effect on cells viability $(\sim 95 \%$ viable cells at $100 \mu \mathrm{g} / \mathrm{mL})$, while both inclusion complexes, TE/ $\beta \mathrm{CD}$ and $\mathrm{TE} / \gamma \mathrm{CD}$ induced a reduction of cell viability in a concentration dependent manner. The lowest value of $\mathrm{MCF}-7$ viable cells was obtained for $\mathrm{TE} / \beta \mathrm{CD}$ at $100 \mu \mathrm{g} / \mathrm{mL} \sim 63 \%$. In the case of MDA-MB-231 cells, it was observed the same activity, but more pronounced even in the case of TE. The following data were obtained: $\sim 60 \%$ viable cells at $100 \mu \mathrm{g} / \mathrm{mL} \mathrm{TE,} 49 \%$ viable cells at $100 \mu \mathrm{g} / \mathrm{mL} \mathrm{TE} / \beta C D$ and $\sim 32 \%$ viable cells at 100 $\mu \mathrm{g} / \mathrm{mL} \mathrm{TE} / \gamma \mathrm{CD}$ (see Figure 5). 
MCF-7

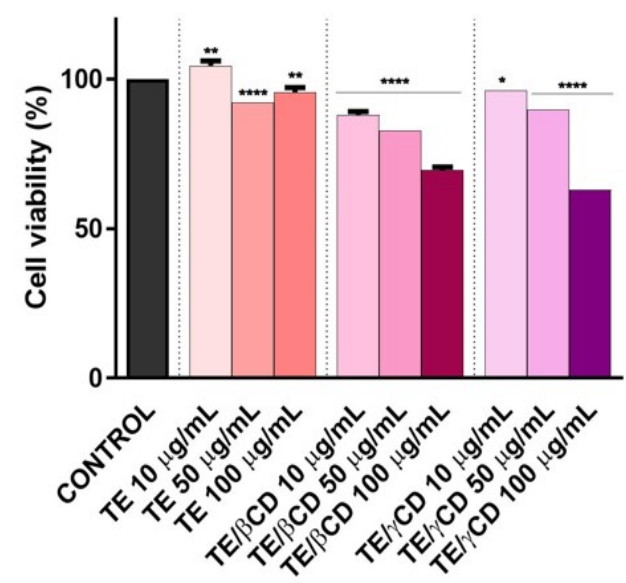

MDA-MB-231

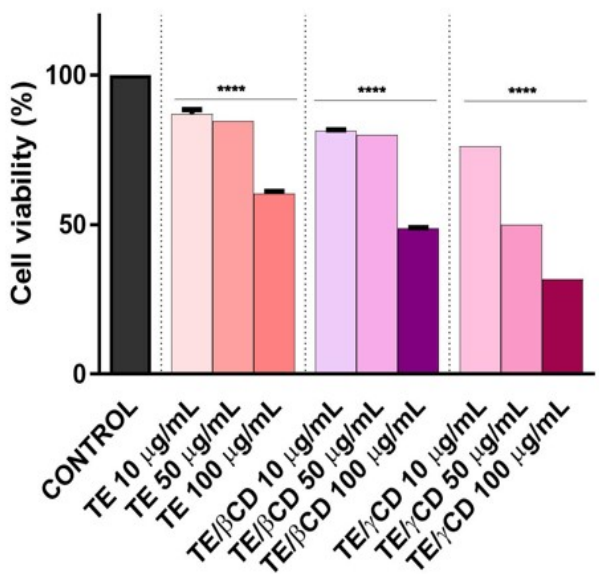

Figure 5.

Viability percentage of MCF-7 and MDA-MB-231 (human breast cancer cells) at $24 \mathrm{~h}$ post-stimulation with thyme total hydro-alcoholic extract and its inclusions complexes with $\beta$ - and $\gamma$-cyclodextrins $(10,50$ and $100 \mu \mathrm{g} / \mathrm{mL})$

Figure 6 reveals the migratory capacity of the normal cells in the presence of TE, TE/ $\beta C D$ and TE/ $\gamma \mathrm{CD}$. The concentration applied for this analysis was the lowest, namely $10 \mu \mathrm{g} / \mathrm{mL}$ for better observation of cells behaviour. After TE stimulation, no interference was observed, the cells grew normally. The same remarks can be made and related to the stimulation with $\mathrm{TE} / \beta \mathrm{CD}$ while in the case of $\mathrm{TE} / \gamma \mathrm{CD}$ a stimulatory effect on the cells was observed (Figure 6).
CONTROL

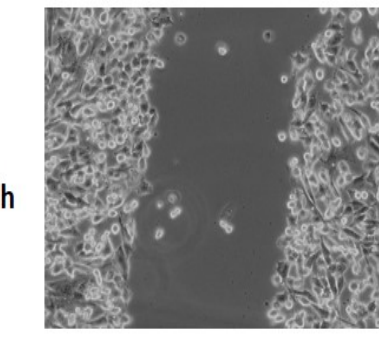

$24 \mathrm{~h}$

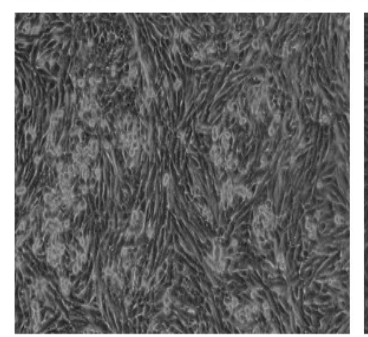

TE
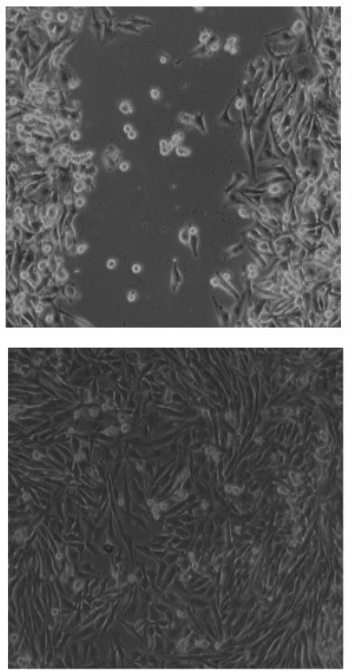

$\mathrm{TE} / \mathrm{bCD}$
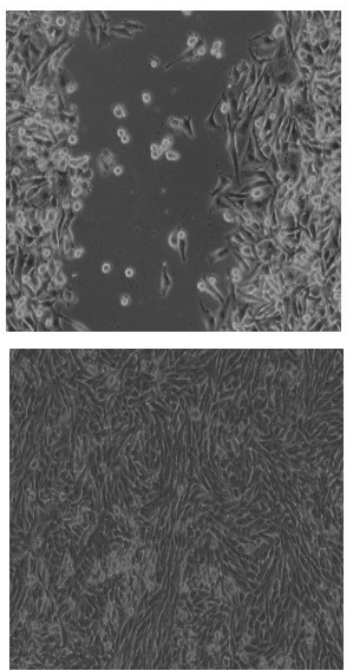

$\mathrm{TE} / \mathrm{gCD}$
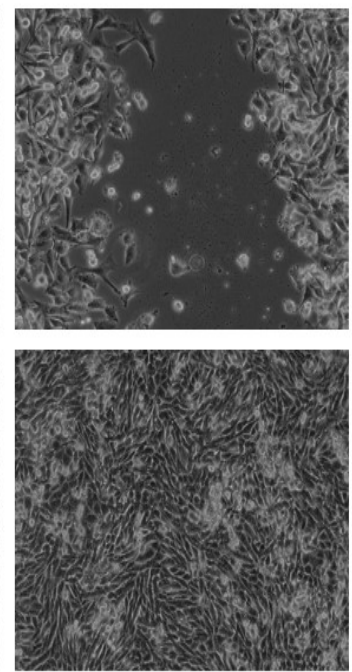

Figure 6.

The impact of thyme total hydro-alcoholic extract and its inclusions complexes with $\beta$ - and $\gamma$ - cyclodextrins (TE, $\mathrm{TE} / \beta \mathrm{CD}$, and $\mathrm{TE} / \gamma \mathrm{CD} 10 \mu \mathrm{g} / \mathrm{mL}$ ) on the migratory capacity of normal cells (HaCaT)

The in vitro scratch assay showed that the breast cancer cells, MCF-7 and MDA-MB-231, migratory capacity was slightly inhibited in a different manner by the tested compounds. After MCF-7 cells stimulation with TE and TE/ $\gamma \mathrm{CD}$ no significant influence was observed; moreover, a stimulatory effect could be noticed, while in the case of TE/ $\beta C D$ the partial filling with the cells of the trace line can be easily observed (Figure 7). On the other hand, after stimulation with the samples, MDA-MB-231 cells are clearly influenced in terms of cell migration and proliferation by the TE/ $\gamma \mathrm{CD}$ and for TE and TE/ $\beta C D$, there is a slight inhibition of these processes, as it can be seen in the Figure 8, data that are consistent with the results from cells viability assessment. 


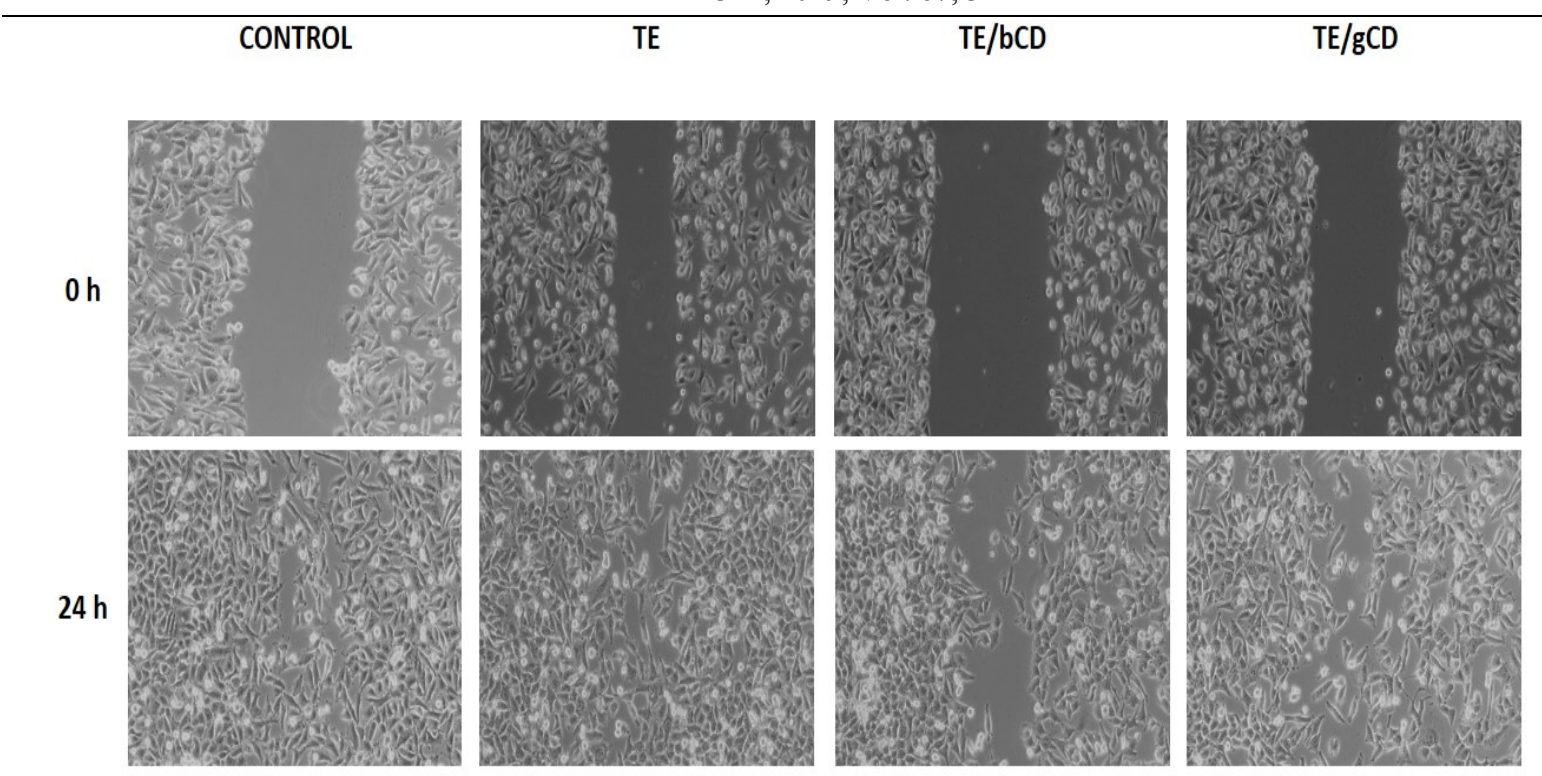

Figure 7.

The impact of thyme total hydro-alcoholic extract and its inclusions complexes with $\beta$ - and $\gamma$-cyclodextrins (TE, $\mathrm{TE} / \beta \mathrm{CD}$, and $\mathrm{TE} / \gamma \mathrm{CD} 10 \mu \mathrm{g} / \mathrm{mL}$ ) on the migratory capacity of tumoral cells (MCF-7)

CONTROL

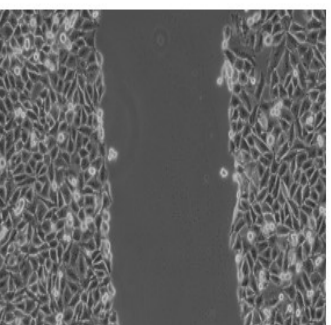

$24 \mathrm{~h}$

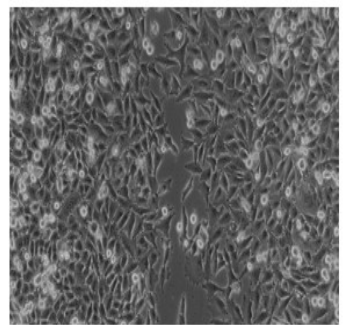

TE
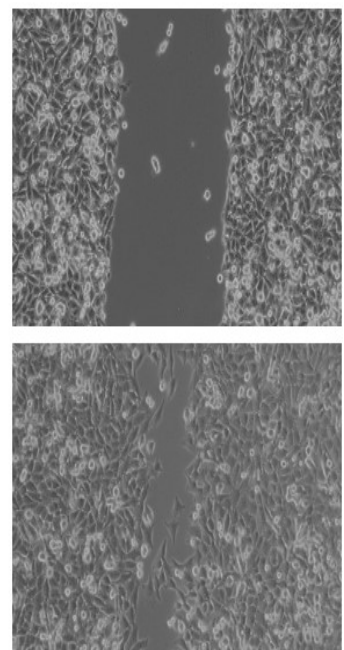

$\mathrm{TE} / \mathrm{bCD}$
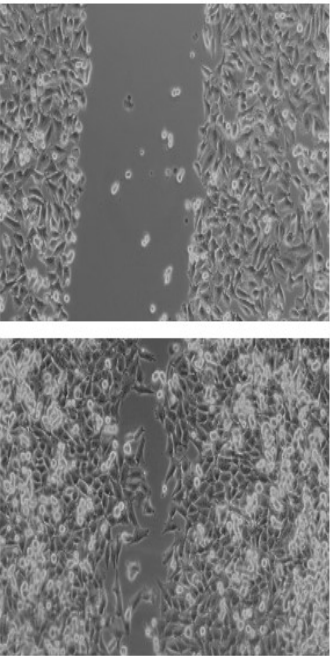

$\mathrm{TE} / \mathrm{gCD}$
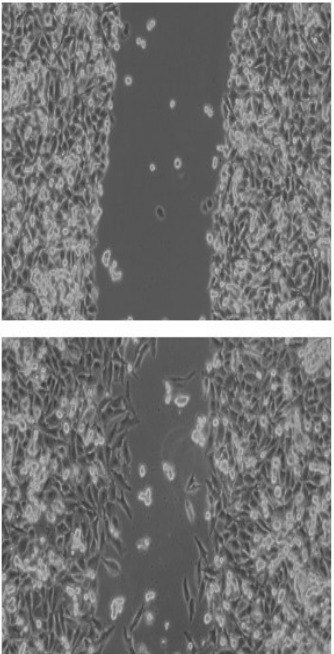

Figure 8.

The impact of thyme total hydro-alcoholic extract and its inclusions complexes with $\beta$ - and $\gamma$-cyclodextrins (TE, $\mathrm{TE} / \beta \mathrm{CD}$, and $\mathrm{TE} / \gamma \mathrm{CD} 10 \mu \mathrm{g} / \mathrm{mL}$ ) on the migratory capacity of tumoral cells (MDA-MB-231)

In Figure 9 is presented the effect of the samples on MCF-7 and MDA-MB-231 breast cancer cells apoptotic status. At $100 \mu \mathrm{g} / \mathrm{mL}$ it was recorded a significant increase of dead cells, a pronounced pro-apoptotic effect, and the highest percentage of apoptotic cells was determined by inclusion complexes in both cell types: $~ 31 \%$ (TE/ $/ \mathrm{CD})$ and $~ 37 \%$ (TE/ $/ \mathrm{CD}) \mathrm{MCF}-7$ apoptotic cells, and $\sim 37 \%(\mathrm{TE} / \beta \mathrm{CD})$ and $\sim 86 \%$
(TE/ $\gamma \mathrm{CD})$ MDA-MB-231 apoptotic cells (Figure 9). The cells status was assessed by a FACS technique, represented in four quadrants: Q1 with necrotic cells, Q2 with late apoptotic cells, Q3 with early apoptotic cells, and Q4 with viable cells. In Figure 9 are expressed only early apoptotic cells which are calculated as percentage of apoptotic cells compared to untreated cells. 


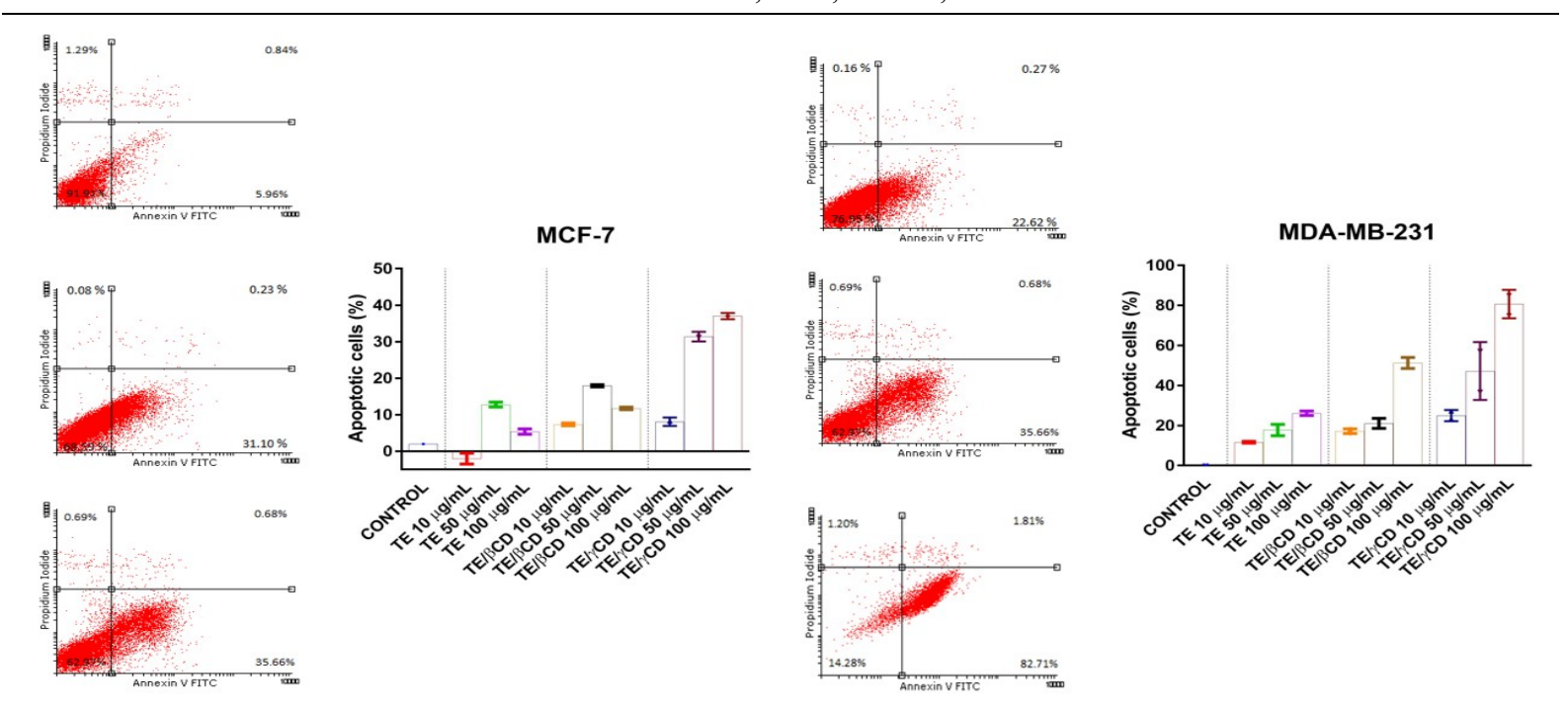

Figure 9.

Representative dot plots of the apoptotic events induced by thyme total hydro-alcoholic extract and its inclusions complexes with $\beta$ - and $\gamma$-cyclodextrins (TE, TE $/ \beta C D$, and TE $/ \gamma C D$ 10, 50, and $100 \mu \mathrm{g} / \mathrm{mL}$ ) in MCF-7 and

MDA-MB-231 breast cancer cells after a $24 \mathrm{~h}$ stimulation

Biologically active compounds permanently attract the attention of researchers in the medical/pharmaceutical fields due to the promising activity they exert on the tumour cells. Thyme extract and its individual bioactive constituents represented the subject of various studies conducted in the field. For example, Abaza et al. studied the activity of isolated naringenin from Thymus vulgaris extract on colorectal and breast cancer cells and showed that the compound induces apoptosis and potentiates the viability of tumoral cells through multifactorial mechanisms (e.g. cell cycle arrest, up-regulation and down-regulation specific genes, inhibition of pro-survival signalling pathways); Arunasree presented the anti-proliferative effect of carvacrol in human breast cancer cells, with an $\mathrm{IC}_{50}$ value of $100 \mu \mathrm{M}[1,3]$. Bozkurt et al. stimulated human breast cancer cells, MCF-7 and MDA-MB231, with Thymus serpyllum methanolic extract and, at $72 \mathrm{~h}$ post-stimulation the $\mathrm{IC}_{50}$ values obtained were $509 \mu \mathrm{g} / \mathrm{mL}$ and $276 \mu \mathrm{g} / \mathrm{mL}$ [7]. In another study regarding the evaluation of MCF-7 cells viability in the presence of different extracts from Lamiaceae family was observed that Thymus vulgaris and Thymus serpyllum aqueous extracts performed almost similar activity, the $\mathrm{IC}_{50}$ values recorded being 407 and 399 $\mu \mathrm{g} / \mathrm{mL}$, respectively [4].

\section{Conclusions}

In summary, related to the considerable biological effect of phytochemicals on pathologies considered for the time being incurable, the current research was performed in order to evaluate the antioxidant, antiproliferative and antitumoral effects of TE on human breast cancer cells. To enhance the stability and solubility of TE, the inclusion complexes with $\beta$ - and $\gamma$-cyclodextrins were prepared successfully and the formation of the supramolecular systems was confirmed by SEM, DSC and FTIR. The compounds shown significant antioxidant activity over different time intervals, which highlights the controlled release of biologically active compounds from extract. TE/ $\beta C D$ and $\mathrm{TE} / \gamma \mathrm{CD}$ denoted a significant cytotoxic activity on MCF-7 and MDA-MB-231cells, with the most notable activity of the TE/ $\gamma \mathrm{CD}$ complex on cells that expressed epidermal growth factor (EGF) and transforming growth factor alpha (TGF alpha).

\section{References}

1. Abaza MSI, Orabi KY, Al-Quattan E, Al-Attiyah RJ, Growth inhibitory and chemo-sensitization effects of naringenin, a natural flavanone purified from Thymus vulgaris, on human breast and colorectal cancer. Cancer Cell Int., 2015; 15: 1-19.

2. Andor B, Danciu C, Alexa E, Zupko I, Hogea E, Cioca A, Coricovac D, Pinzaru I, Pătrașcu JM, Mioc M, Romeo C, Soica C, Dehelean C, Germinated and ungerminated seeds extract from two Lupinus species: biological compounds characterization and in vitro and in vivo evaluations. Evid Based Complement Alternat Med., 2016; 2016: 1-8.

3. Arunasree KM, Anti-proliferative effects of carvacrol on a human metastatic breast cancer cell line, MDAMB 231. Phytomedicine, 2010; 17(8-9): 581-588.

4. Berdowska I, Zieliński B, Fecka I, Kulbacka J, Saczko J, Gamian A, Cytotoxic impact of phenolics from Lamiaceae species on human breast cancer cells. Food Chem., 2013; 141(2): 1313-1321.

5. Bishayee A, Ahmed S, Brankov N, Perloff M, Triterpenoids as potential agents for the chemoprevention and therapy of breast cancer. Front Biosci., 2011; 16: 980-996.

6. Boros B, Jakabová S, Dörnyei A, Horváth G, Pluhár Z, Kilár F, Felinger A, Determination of polyphenolic 
compounds by liquid chromatography-mass spectrometry in Thymus species. J Chromatogr A, 2010; 1217(51): 7972-7980.

7. Bozkurt E, Atmaca H, Kisim A, Uzunoglu S, Uslu R, Karaca B, Effects of Thymus serpyllum extract on cell proliferation, apoptosis and epigenetic events in human breast cancer cells. Nutr Cancer., 2012; 64(8): 1245-1250

8. Corina D, Florina B, Iulia P, Cristina D, Rita A, Alexandra P, Virgil P, Hancianu M, Daliana M, Codruta S, Rutin and its cyclodextrin inclusion complexes: physico-chemical evaluation and in vitro activity on B164A5 murine melanoma cell line. Curr Pharm Biotechnol., 2017; 18(13): 10671077.

9. Dai J, Mumper RJ, Plant phenolics: Extraction, analysis and their antioxidant and anticancer properties. Molecules, 2010; 15: 7313-7352.

10. Danciu C, Pinzaru IA, Dehelean CA, Hancianu M, Zupko I, Navolan D, Licker M, Ghiulai RM, Şoica $\mathrm{CM}$, Antiproliferative and antimicrobial properties of pure and encapsulated rutin. Farmacia, 2018; 66(2): 302-308.

11. Dandawate PR, Subramaniam S, Jensen RA, Anant S, Targeting cancer stem cells and signaling pathways by phytochemicals: Novel approach for breast cancer therapy. Seminars in Cancer Biology, 2016; 40-41: 192-208.

12. Heidari Z, Salehzadeh A, Shandiz SAS, Tajdoost S, Anti cancer and anti oxidant properties of ethanolic leaf extract of Thymus vulgaris and its bio functionalized silver nanoparticles. 3Biotech., 2018; 8: 1-14.
13. Laza-Knoerr AL, Gref R, Couvreur P, Cyclodextrins for drug delivery. J Drug Target., 2010; 18(9): 645656.

14. Loftsson T, Brewster ME, Pharmaceutical applications of cyclodextrins. 1. Drug solubilization and stabilization. J Pharm Sci., 1996; 85: 1017-1025.

15. Kurkov SV, Loftsson T, Cyclodextrins. Int J Pharm., 2013; 453(1): 167-180.

16. Pan SY, Zhou SF, Gao SH, Yu ZL, Zhang SF, Tang MK, Sun JN, Ma DL, Han YF, Fong WF, Ko KM, New perspectives on how to discover drugs from herbal medicines: cam's outstanding contribution to modern therapeutics. Evid Based Complement Alternat Med., 2013; 2013: 1-25.

17. Pinho E, Grootveld M, Soares G, Henriques M, Cyclodextrins as encapsulation agents for plant bioactive compounds. Carbohydr Polym., 2014; 101: 121-135.

18. Pinzaru I, Heghes A, Marti D, Dehelean C, Coricovac D, Moaca A, Moatar M, Came D, Therapeutically potential of Medicago sativa extracts chemical and in vitro assessments. Rev Chim., 2018; 69(1): 121-124.

19. Pinzaru IA, Hadaruga DI, Hadaruga NG, Corpas L, Grozescu I, Peter F, Hepatoprotective flavonoid bioconjugate/ $\beta$-cyclodextrin nanoparticles: DSCmolecular modeling correlation. Dig J Nanomateri Biostruct., 2011; 6(4): 1605-1617.

20. Raudone L, Zymone K, Raudonis R, Vainoriene R, Motiekaityte V, Janulis V, Phenological changes in triterpenic and phenolic composition of Thymus L. species. Ind Crops Prod., 2017; 109: 445-451.

21. Suvarna V, Gujar P, Murahari M, Complexation of phytochemicals with cyclodextrin derivatives - An insight. Biomed Pharmacother., 2017; 88: 1122-1144. 